\title{
ANALISIS TINGKAT POPULASI JAMUR TANAH \\ DI LAHAN PERTANAMAN KENTANG (Solanum tuberosum L.) BERDASARKAN METODE TOTAL PLATE COUNT (TPC)
}

\author{
Windha Arantika ${ }^{\text {() }}$, Stella D. Umboh ${ }^{1)}$, Johanis J. Pelealu ${ }^{1)}$ \\ 1) Program Studi Biologi, Fakultas Matematika dan Ilmu Pengetahuan Alam Universitas Sam Ratulangi \\ E-mail: arantikawindha4@gmail.com
}

\begin{abstract}
ABSTRAK
Penelitian ini bertujuan untuk mengetahui tingkat populasi jamur tanah di lahan pertanaman kentang ( $S$. tuberosum L.). Sampel tanah diambil di perkebunan tanaman kentang Desa Pinasungkulan Kecamatan Modoinding yang banyak menggunakan pestisida. Penelitian ini dilakukan dengan mengisolasi jamur pada tanah di pertanaman kentang di Desa Pinasungkulan, Kecamatan Modoinding, Kabupaten Minahasa Selatan dengan pengenceran bertingkat dan dilanjutkan dengan menghitung jumlah koloni dengan metode Total Plate Count (TPC). Dari hasil isolasi diperoleh 6 famili dengan 11 jenis jamur tanah yang memiliki koloni terbesar pada isolat $\mathrm{KJ} 1$ sebesar 71 koloni dan terendah pada isolat $\mathrm{KJ} 8$, KJ10, dan $\mathrm{KJ} 11$ masing-masing sebesar 2 koloni.
\end{abstract}

Kata kunci: Tanaman kentang, jamur tanah, tingkat populasi, Total Plate Count (TPC)

\section{ANALYSIS OF SOIL FUNGUS POPULATION LEVELS \\ IN POTATO PLANTS (Solanum tuberosum L.) \\ BASED ON TOTAL PLATE COUNT (TPC) METHODS}

\begin{abstract}
This study aimed to determine the level of soil fungus population on potato planting land ( $\mathrm{S}$. tuberosum L.). Soil samples were taken at a potato field plantation in Pinasungkulan Village, Modoinding Subdistrict, which used many pesticides. This research was carried out by isolating fungi on soil in potato plantations in Pinasungkulan Village, Modoinding District, South Minahasa Regency with multilevel dilution and continued by counting the number of colonies using the Total Plate Count (TPC) method. The result showed that the isolation obtained 6 families with 11 types of soil fungi that have the largest colony in $\mathrm{KJ} 1$ isolates of 71 colonies and the lowest in isolates $\mathrm{KJ} 8, \mathrm{KJ} 10$, and $\mathrm{KJ} 11$ of 2 colonies respectively.
\end{abstract}

Keywords: Potato plants, soil fungi, population level, Total Plate Count (TPC)

Article History:

Received: July 11, $2019 \quad$ Accepted: July 24, $2019 \quad$ Published: July 25, 2019

\section{PENDAHULUAN}

Tanaman kentang (Solanum tuberosum) adalah salah satu tanaman sayuran yang berumur pendek dan menjadi prioritas untuk dikembangkan di Indonesia karena memiliki nilai ekonomis yang tinggi dan memberikan keuntungan bagi para petani karena harga umbinya yang relatif stabil. Nilai gizi pada tanaman kentang tergolong tinggi yang menyebabkan banyak produksi kentang diberbagai wilayah, termasuk di daerah yang kurang produktif (Rubatzky dan Yamaguchi, 1998 dalam Arivin et al., 2014).

Peranan kentang di Indonesia semakin meningkat, baik dalam bentuk produk yang masih segar maupun dalam bentuk produk olahan. Di Provinsi Sulawesi Utara, tanaman kentang merupakan komoditas unggulan yang telah memberi 
kontribusi pasokan terhadap produksi kentang nasional. Pemerintah Daerah Sulawesi Utara menetapkan kentang sebagai salah satu komoditi unggulan daerah baik ditinjau dari capaian produksi maupun dari skala usaha ekonomi karena areal perkentangan dapat mencapai lebih dari 10.000 ha (Tomayahu, 2015).

Kecamatan Modoinding adalah salah satu kecamatan di Sulawesi Utara yang merupakan wilayah yang potensial untuk pengembangan agrobisnis kentang karena berbagai sumberdaya (resources) yang ada sangat mendukung upaya ini. Sampai saat ini hasil produksi tanaman kentang di Kecamatan Modoinding dapat mencapai lebih dari 30 ton/ha sedang produksi rata-rata yang dicapai petani sekitar 15-20 ton/ha (Anonim, 2001 dalam Tomahayu, 2015). Salah satu penyebab rendahnya produksi kentang adalah adanya hama dan penyakit yang menyerang daun, batang, dan umbi. Hama dan penyakit merupakan salah satu faktor pembatas biologis dan ancaman yang menyebabkan rendahnya produksi yang dicapai petani. Adanya hama dan penyakit tersebut dapat menyebabkan kerusakan pada tanaman jika tidak dikendalikan dan produktivitas tanaman akan berkurang. Hal tersebut dapat memberi kerugian bagi petani secara kualitas maupun kuantitas (Sembel, 1990; Taulu dan Krisen, 2003).

Pestisida adalah bahan kimia yang digunakan untuk mengendalikan perkembangan dan pertumbuhan dari hama, penyakit, dan gulma. Pengendalian hama dengan menggunakan pestisida sintetik masih merupakan teknik pengendalian yang utama (Adawiah, 2016). Penggunaan pestisida sintetik ini memberi dampak negatif tidak saja pada lingkungan pertanian tapi juga dapat membahayakan kehidupan manusia dan hewan dimana residu pestisida terakumulasi pada produk-produk pertanian dan perairan. Keberadaan pestisida tidak akan bermasalah sepanjang penggunaannya terkendali dan tepat, namun implikasi terhadap kehidupan mikroba tanah perlu diperhitungkan (Sulistinah, 2011).

Penggunaan pestisida dalam memberantas hama atau penyakit tertentu sering mensterilisasi ekosistem tanah, sehingga populasi bakteri dan jamur di dalam tanah menurun, padahal keberadaan bakteri dan jamur di dalam tanah sangat bermanfaat untuk pertumbuhan tanaman. Jamur tanah terutama di daerah rhizosfer perakaran tanaman kentang membantu pertumbuhan tanaman melalui berbagai mekanisme seperti peningkatan penyerapan nutrisi, sebagai kontrol biologi terhadap serangan patogen, dan juga menghasilkan hormon pertumbuhan bagi tanaman (Chanway, 1997).

Informasi tentang tingkat populasi jamur tanah yang terpapar pestisida sintetik di lahan pertanaman kentang yang ada di Kecamatan Modoinding masih sedikit. Oleh sebab itu perlu dilakukan penelitian tentang tingkat populasi jamur tanah tersebut.

Tujuan penelitian ini, yaitu mengetahui tingkat populasi jamur tanah di lahan pertanaman kentang (S. tuberosum L.).

\section{METODE PENELITIAN}

\section{Waktu dan Tempat}

Penelitian ini dilaksanakan pada bulan Februari 2019 sampai dengan bulan April 2019 di Laboratorium Advance Mikrobiologi Jurusan Biologi Fakultas Matematika dan Ilmu Pengetahuan Alam, Universitas Sam Ratulangi, Manado.

\section{Alat dan Bahan}

Alat dan bahan yang digunakan dalam penelitian ini yaitu plastik ziplock, alumunium foil, kertas label, gunting, timbangan analitik, kapas cotton ball, hotplate, tabung reaksi, suntik, vortex, cawan petri, kaca objek dan kaca penutup, mikroskop, autoklaf, laminar, bor tanah, sampel tanah, Potato Dextrose Agar (PDA), kotrimoksazol, metilen blue, akuades, alkohol $70 \%$.

\section{Prosedur Penelitian}

Pengambilan sampel tanah dilakukan di daerah pertanaman tanaman kentang yang berada di Desa Pinasungkulan Kecamatan Modoinding yang banyak menggunakan pestisida. Sampel tanah di ambil dari lima bedeng. Setiap bedeng diambil lima sampel tanah pada kedalaman $0-30 \mathrm{~cm}$ sebanyak 1 $\mathrm{kg}$ yang dikompositkan menjadi satu, sehingga jumlah keseluruhan sampel tanah yang diuji menjadi lima sampel. Sampel tanah dimasukkan ke dalam plastik ziplock steril dan selanjutnya dibawa ke 
Laboratorium Advance Mikrobiologi Jurusan Biologi Fakultas Matematika dan Ilmu Pengetahuan Alam, Universitas Sam Ratulangi, Kota Manado untuk dilakukan pengujian tingkat populasi jamur tanah dengan proses pengenceran bertingkat. Koloni jamur yang tumbuh dari hasil isolasi dihitung menggunakan metode Total Plate Count (TPC), dimana setiap sel yang ada dianggap dapat hidup dan berkembang menjadi satu koloni dan koloni tersebutlah yang akan dihitung. Perhitungannya berdasarkan rumus:

$\mathrm{CFU} / \mathrm{mL}=\frac{\text { Jumlah Rata }- \text { rata Koloni }}{\text { Volume Inokulum } \mathrm{x} \text { Faktor Pengenceran }}$

\section{HASIL DAN PEMBAHASAN}

Jumlah populasi jamur tanah dalam penelitian ini dapat diketahui dengan metode pengenceran bertingkat yaitu empat seri pengenceran $\left(10^{-2}, 10^{-3}, 10^{-4}\right.$, dan $\left.10^{-5}\right)$. Dari 5 sampel tanah dan 4 seri pengenceran diperoleh 170 koloni yang tumbuh dengan 11 jenis jamur tanah (Chrysonilia sitophila, Microsporum sp.1, Microsporum sp.2, Chrysosporium sp., Mucor sp., Penicillium citrinum, Fusarium oxysporum, Scytalidium sp., Rhizopus sp., Tricophyton sp. 1, dan Tricophyton sp. 2,). Jumlah koloni jamur tanah tertinggi pada isolat jamur $\mathrm{KJ} 1(C$. sitophila) pada sampel tanah E (71 koloni) pada pengenceran $10^{-2}$, yang masuk pada jamur dengan pertumbuhan tercepat dan memiliki kemampuan adaptasi yang tinggi sedangkan pertumbuhan yang lambat yaitu isolat $\mathrm{KJ} 8 \quad$ (Scytalidium $s p$.), $\mathrm{KJ} 10$ (Trichophyton sp.1), dan KJ11 (Trichophyton sp.2) dengan jumlah koloni terendah (masing-masing 2 koloni). Secara keseluruhan jumlah koloni jamur dari setiap pengenceran dapat dilihat pada Tabel 1 .

Menurut Gandjar et al. (1999), ada beberapa jenis jamur yang umum terdapat di dalam tanah dan bahan organik, seperti Aspergillus oryzae, Chrysonilia sitophila, Mucor, Rhizopus, dan banyak lagi jenis jamur yang dapat dijumpai. Setelah diidentifikasi terlihat adanya spesies jamur tanah yang dominan tumbuh di 4 seri pengenceran yaitu dari Famili Arthrodermataceae dengan 5 isolat yaitu antara lain: $\mathrm{KJ} 2$ (Micrsoporum sp. 1), KJ3
(Micrsoporum sp. 2), KJ4 (Chrysosporium sp.), KJ10 (Trichophyton sp. 1), dan KJ10 (Trichophyton sp. 2).

Hanya jamur dari famili Arthrodermataceae yang pertumbuhannya mendominasi dibandingkan dengan famili yang lainnya, hal ini karena kemungkinan disebabkan oleh pestisida dan pupuk yang digunakan secara terus menerus oleh petani selama bertahun-tahun yang dapat membunuh mikrorganisme khususnya jamur tanah yang terdapat pada lahan tanaman kentang tersebut. Berdasarkan informasi dari petani-petani holtikultura yang ada di Kecamatan Modoinding, pestisida yang banyak digunakan adalah Curacron 500 EC dengan bahan aktif Profenofos dari golongan Organofosfat yang memiliki sifat yang tidak persisten, polar, dan mudah larut dalam air. Meskipun demikian, jika penggunaannya kontinu oleh petani setempat akan memberikan masukan yang kontinu pula terhadap tanah.

Umboh (2016) melakukan pengujian terhadap kandungan residu pestisida di lahan pertanaman hortikultura di Kecamatan Modoinding, dan diperoleh residu pestisida golongan Organoklorin walaupun sudah dilarang peredarannya seperti: Lindan ( $\mathrm{g}$ BHC), Aldrin, Heptaklor, Dieldrin, Endrin, dan Endosulfan masih bisa terdeteksi ada di dalam tanah. Hal ini menunjukkan residu pestisida tersebut lebih lambat terdegradasi dibandingkan dengan golongan pestisida lainnya dan lebih lama berada di dalam tanah, dengan demikian kemungkinan populasi jamur tanah menurun sangat besar karena golongan Organoklorin sifatnya persisten, terikat kuat pada partikel tanah, daya larut yang rendah sehingga berpotensi terakumulasi pada tubuh mahluk hidup terutama pada tubuh jamur tanah.

Nasahi (2010) mengatakan, penggunaan pestisida selama bertahun-tahun dapat mengurangi keanekaragaman organisme tanah. Jamur yang masih dapat bertahan hanyalah jamur yang memiliki kemampuan adaptasi yang tinggi atau jamur yang sudah mengalami koevolusi. Jamur dapat bertahan hidup apabila dapat menyesuaikan diri dengan lingkungannya, juga dapat tumbuh selama kondisi lingkungan menguntungkan. 
Tabel 1. Jumlah Koloni Jamur Tanah Yang Tumbuh Pada Lima Sampel Tanah Dengan Empat Seri Pengenceran

\begin{tabular}{|c|c|c|c|c|c|c|c|c|c|c|c|c|c|}
\hline \multirow{2}{*}{ No } & \multirow{2}{*}{$\begin{array}{c}\text { Sampel dan } \\
\text { Pengenceran }\end{array}$} & \multicolumn{11}{|c|}{ Isolat Jamur } & \multirow[b]{2}{*}{ Tota } \\
\hline & & KJ1 & $\mathrm{KJ} 2$ & $\mathrm{KJ} 3$ & KJ4 & KJ5 & KJ6 & KJ7 & KJ8 & KJ9 & KJ10 & KJ11 & \\
\hline 1 & SA1 & 13 & 0 & 0 & 0 & 0 & 0 & 0 & 0 & 0 & 0 & 0 & 13 \\
\hline 2 & SA2 & 0 & 0 & 5 & 0 & 0 & 0 & 0 & 0 & 0 & 0 & 0 & 5 \\
\hline 3 & SA3 & 6 & 0 & 0 & 0 & 0 & 0 & 0 & 0 & 0 & 0 & 0 & 6 \\
\hline 4 & SA4 & 1 & 0 & 1 & 0 & 0 & 0 & 0 & 0 & 1 & 0 & 0 & 3 \\
\hline 5 & SB1 & 2 & 0 & 0 & 0 & 9 & 2 & 0 & 0 & 0 & 0 & 0 & 13 \\
\hline 6 & SB2 & 5 & 1 & 0 & 0 & 0 & 2 & 0 & 0 & 1 & 0 & 0 & 9 \\
\hline 7 & SB3 & 0 & 1 & 0 & 0 & 3 & 0 & 2 & 0 & 0 & 0 & 0 & 6 \\
\hline 8 & SB4 & 0 & 0 & 0 & 2 & 0 & 0 & 0 & 0 & 0 & 0 & 0 & 2 \\
\hline 9 & $\mathrm{SC} 1$ & 24 & 0 & 0 & 0 & 0 & 0 & 0 & 0 & 0 & 0 & 0 & 24 \\
\hline 10 & $\mathrm{SC} 2$ & 4 & 0 & 0 & 0 & 1 & 1 & 0 & 0 & 0 & 0 & 2 & 8 \\
\hline 11 & $\mathrm{SC} 3$ & 5 & 0 & 0 & 0 & 0 & 0 & 0 & 0 & 0 & 0 & 0 & 5 \\
\hline 12 & $\mathrm{SC} 4$ & 4 & 0 & 0 & 0 & 2 & 1 & 0 & 0 & 0 & 0 & 0 & 7 \\
\hline 13 & SD1 & 0 & 0 & 0 & 3 & 8 & 8 & 0 & 0 & 0 & 0 & 0 & 19 \\
\hline 14 & SD2 & 5 & 0 & 0 & 0 & 1 & 0 & 0 & 0 & 0 & 0 & 0 & 6 \\
\hline 15 & SD3 & 0 & 0 & 1 & 1 & 0 & 2 & 1 & 1 & 0 & 0 & 0 & 6 \\
\hline 16 & SD4 & 2 & 0 & 0 & 0 & 0 & 0 & 0 & 1 & 0 & 0 & 0 & 3 \\
\hline 17 & SE1 & 0 & 1 & 0 & 0 & 0 & 13 & 0 & 0 & 2 & 1 & 0 & 17 \\
\hline 18 & SE2 & 0 & 0 & 0 & 1 & 2 & 6 & 0 & 0 & 1 & 0 & 0 & 10 \\
\hline 19 & SE3 & 0 & 0 & 0 & 0 & 0 & 0 & 0 & 0 & 0 & 0 & 0 & 3 \\
\hline 20 & SE4 & 0 & 0 & 0 & 1 & 0 & 1 & 0 & 0 & 0 & 1 & 0 & 3 \\
\hline & Jumlah & 71 & 3 & 7 & 8 & 26 & 36 & 3 & 2 & 5 & 2 & 2 & 170 \\
\hline
\end{tabular}

Ket. SA1,2,3,4 = Sampel Tanah A pada Pengenceran $10^{-2}, 10^{-3}, 10^{-4}, 10^{-5}$ SB1,2,3,4 = Sampel Tanah A pada Pengenceran $10^{-2}, 10^{-3}, 10^{-4}, 10^{-5}$ SC1,2,3,4 = Sampel Tanah A pada Pengenceran $10^{-2}, 10^{-3}, 10^{-4}, 10^{-5}$ SD1,2,3,4 = Sampel Tanah A pada Pengenceran $10^{-2}, 10^{-3}, 10^{-4}, 10^{-5}$ SE1,2,3,4 = Sampel Tanah A pada Pengenceran $10^{-2}, 10^{-3}, 10^{-4}, 10^{-5}$ $\mathrm{KJ}=$ Isolat Jamur

bagi pertumbuhan dan pertahanannya. Dengan demikian faktor lingkungan mempengaruhi dinamika jamur karena sifat selektif terhadap keberadaan populasinya (Pelczar dan Chan, 1986 dalam Pangestu 2009; Costerton, 2004).

Hasil penelitian memperlihatkan jumlah spora $\mathrm{CFU} / \mathrm{mL}$ tertinggi terdapat pada jamur KJ1 (Chrysonilia sitophila) yaitu 2,1x10-5, dan jumlah spora CFU/mL terendah pada jamur KJ11 (Trichopyton sp. 2) sebesar 0,1x10-5. Hasil ini diduga dipengaruhi oleh penggunaan insektisida di lahan tanaman kentang yang dapat meninggalkan residu dan bioakumulasinya memberikan dampak terhadap kehidupan mikroorganisme tanah terutama tingkat populasi jamur tanah. Hasil ini didukung oleh hasil penelitian yang dilakukan oleh Umboh (2016), dimana dari 5 perlakuan pestisida (Organofosfat, Organoklorin,
Karbamat, Difenil, dan Biopestisida/Bacillus thuringiensis),

aplikasi insektisida Organofosfat dengan pemberian bahan aktif Profenofos dapat menurunkan dan mengubah jumlah jamur tanah, ditandai dengan jumlah spora $\mathrm{CFU} / \mathrm{mL}$ pada perlakuan dengan aplikasi pestisida lebih rendah (6x10-6) dibandingkan dengan kontrol (9.6x10-6). Menurut Greaves dan Malkomes (1980) dalam Noya (2004) bahwa perubahan populasi mikroorganisme tanah dapat digunakan untuk memprediksi dampak penggunaan insektisida terhadap tanah.

Dugaan penurunan jumlah populasi jamur tanah di atas sama seperti pernyataan dari Paul dan Clark (1997) dalam Humaidi et al. (1999) yang mengatakan bahwa penurunan jumlah populasi jamur tanah juga diduga disebabkan oleh tingginya penggunaan bahan aktif pestisida untuk 
tanaman dan tanah serta lambatnya tingkat degradasi bahan aktif tersebut di dalam tanah. Lebih lanjut menurut Deacon (1997) bahwa rendahnya populasi jamur tanah diduga karena propagule (konidia) mengalami dormansi (resting spores). Dugaan lain yang mungkin terjadi karena persenyawaan bahan aktif pestisida terakumulasi di tanah dapat mencegah pertumbuhan jamur tanah tanpa membunuh jamur tanah tersebut, proses ini dikenal dengan istilah jamurstatik.

Selain karena faktor di atas, bervariasinya jenis jamur tanah yang diperoleh, diduga dipengaruhi oleh jenis tanaman yang dibudidayakan (Rao, 1994). Selain itu pula dinamika jamur ditentukan oleh jumlah spesies. Angka kekayaan spesies ditentukan oleh luas dan lokasi tempat komunitas berada (Wirakusuma, 2003 dalam Pengestu, 2009). Luas lahan yang digunakan pada penelitian ini hanya berukuran $10 \mathrm{~m} x$ $10 \mathrm{~m}$ yang memungkinkan terbatasnya jumlah jamur yang diperoleh.

Diperoleh bahwa kisaran jumlah spora $\mathrm{CFU} / \mathrm{mL}$ terendah berada pada kisaran 0 0,1x10-5, penurunan jumlah populasi jamur tanah ini selain disebabkan oleh adanya residu pestisida juga karena disebabkan oleh adanya kompetisi untuk nutrient dan ruang, adanya metabolit sekunder yang dapat menghambat jamur yang lain, dan lebih cepat mengabsorbsi nutrisi sehingga pertumbuhannya lebih cepat. Menurut Sudhakaran et al. (2013) apabila kebutuhan nutrisi jamur dalam tanah terpenuhi maka populasinya akan meningkat. Begitu pula menurut Winarso (2005), tingkat populasi jamur tanah dipengaruhi oleh ketersediaan makanan, ketersediaan air, dan ekologi lain yang mendukung.

\section{KESIMPULAN}

Diperoleh 170 koloni yang tumbuh dengan 11 jenis jamur tanah. Jumlah koloni tertinggi terdapat pada KJ1 sebanyak 71 koloni dengan jumlah spora $\mathrm{CFU} / \mathrm{mL}$ yaitu $2,1 \times 10^{-5}$ dan jumlah koloni terendah terdapat pada jamur KJ11 dengan jumlah spora sebesar $0,1 \times 10^{-5}$.

\section{DAFTAR PUSTAKA}

Adawiah, P. R. A. 2016. Isolasi dan Identifikasi Cendawan Indigenous Rhizosfer Tanaman Kentang (Solanum tuberosum L.) Di Buluballea Kelurahan Patappang Kecamatan Tinggimoncong Kabupaten Gowa [Skripsi]. Fakultas Sains dan Teknologi UIN Alauddin, Makassar.

Arivin, M.S., A. Nugroho., A. Suryanto. 2014. Kajian Panjang Tunas dan Bobot Umbi Bibit terhadap Produksi Tanaman Kentang (Solanum tuberosum L.) Varietas Granola. J. Produksi Tanaman. 2(3): 221-229.

Chanway, C.P. 1997. Inoculation of Tree Roots with Plant Growth Promoting Soil Bacteria: An Emerging Technology for Reforestation. Forest Science. 43(1): 96-112.

Costerton, B. 2004. Microbial Ecology Comes Of Age and Joins The General Ecology Community. Proceedings of the National Academy of Sciences. 101(49): 16983-16984.

Deacon, J. 1997. Modern Mycology Third Edition. Blackwell Science Ltd, Victoria, Australia.

Gandjar, I., Samson, R.A., Vermenlen, K.V.D.T., Santoso, I. 1999. Pengenalan Kapang Tropik Umum. Universitas Indonesia, Jakarta.

Humaidi, F., A. Latief., Abadi., Siti., C. S. Rasminah. 1999. Tingkat Residu Fungisida Methyl Thiopanate dalam Tanah pada Tanaman Kentang serta Dampak terhadap Kehidupan Jamur Tanah di Batu Malang. Nasahi, C. 2010. Peran Mikroba dalam Pertanian Organik. Universitas Padjajaran, Bandung.

Noya, A.I. 2004. Residu Insektisida Profenofos pada Sayuran Kubis dan Tanah Andosol Rurukan Kecamatan Tomohon [Tesis]. Pascasarjana Universitas Sam Ratulangi, Manado. 
Pangestu, D. 2009. Isolasi, Identifikasi, Dinamika, dan Skrinning Pertumbuhan Jamur dari Biokonservasi Palm Kernel Meal. Makalah I. FMIPA UI, 2009. http://lontar.ui.ac.id/file?=digital/130 041-T\%2027083-

Isolasi,\%20identifikasi-analisis.pdf [12/05/2019].

Rao, N. S. S. 1994. Mikroorganisme Tanah dan Pertumbuhan Tanaman. Universitas Indonesia Press, Jakarta.

Sembel, D. T. 1990. Beberapa Serangga Hama pada Tanaman Umbi dan Sayur-sayuran. Fakultas Pertanian Unsrat, Manado.

Sudhakaran, M., D. Pamamoorty., S. R. Kumar. 2013. Impact of Conventional, Sustainable and Organic Farming System on Soil Microbial Population and Soil Biochemical Properties, Puducherry, India. International Journal Of Environmental Sciences. Sci. (4)1.
Sulistinah, N., S. Antonius., M. Rahmansyah. 2011. Pengaruh Residu Pestisida Pola Populasi Bakteri dan Fungi Tanah di Rumahkaca. J. Tek. Ling. 12(1): 4353.

Taulu, L. A., dan J. Krisen. 2003. Hama dan Penyakit Penting Kentang di Kecamatan Modoinding dan Modayak. Eugenia.

Tomahayu, E. 2015. Keanekaragaman dan Kemerataan Serangga pada Areal Tanaman Kentang (Solanum Tuberosum L.) Setelah Berbagai Metode Aplikasi Insektisida. $J$. Agrologia. 4(1): 53-59.

Umboh, S. 2016. Analisis Kadar Residu Pestisida dan Bioakumulasinya Terhadap Laba-laba Predator, Fisikokimia dan Biologi Tanah di Pertanaman Sayuran Kubis [Disertasi]. Pascasarjana Universitas Sam Ratulangi, Manado.

Winarso, S. 2005. Kesuburan Tanah: Dasar Kesehatan dan Kualitas Tanah. Gava Media, Yogyakarta. 